14. Hodgkinson, A.: Biochemical aspects of primary hyperparathyroidism: an analysis of 50 cases. Clin. Sci., 25: 231 (1963).

15. King, R. G. and Stanbury, S. W.: Magnesium metabolism in primary hyperparathyroidism. Ann. Intern. Med., 62: 1223 (1965).

16. Kramer, H. J., Backer, A., and Kruck, F.: Inhibition of Intestinal Na-K-ATPase in experimental uremia. Clin. Chim. Acta, 50: 13 (1974).

17. Lifshitz, F., Hawkins, R. L., Diaz-Bensussen, S., and Wapnir, R. A.: Absorption of carbohydrates in malnourished rats. J. Nutr., 102: 1303 (1972).

18. Longnecker, D. S.: Organ distribution of puromycin in rats. A possible basis for selective cytotoxicity. Lab. Invest., 22: 400 (1970).

19. Lowry, O. H., Rosebrough, N. L., Farr, A. L., and Randall, R. J.: Protein measurements with the Folin phenol reagent. J. Biol. Chem., 193: 265 (1951)

20. Luft, J. M.: Improvements in Epoxy Resin Embedding Methods. 3 J. Biophys. Biochem. Cytol., 2: 409 (1961).

21. Malawar, S. J. and Powell, D. W.: An Improved Turbidometric Analysis of Polyethylene Glycol utilizing an Emulsifier. Gastroenterology, 53: 250 (1967)

22. Nagle, R. B., Bulger, R. E., Stricker, G. E., and Benditt, E. P.: Renal tubular effects of the aminonucleoside of puromycin. Lab. Invest., 26: 558 (1972).

23. Phang, J. M., Valle, D. L., Fisher, L., and Granger, A.: Puromycin effect on amino acid transport: differential rates of carrier protein turnover. Am. J. Physiol., 228: 23 (1975)

24. Sabatini, D. D., Bensch, K., and Barnett, R. J.: Cytochemistry and Electron Microscopy: The preservation of cellular ultrastructure and enzymatic activity by aldehyde fixation. J. Cell Biol., 171: 19 (1963).

25. Salazan de Sousa, J., Guerreiro, O., Cunha, A., and Aranjo, J.: The Association of Nephrotic Syndrome with Intestinal Lymphangiectasia. Archs. Dis. Child. 43: 245 (1968).

26. Saunders, S. J. and Isselbacher, K. J.: Intestinal absorption of aminoacids. Gastroenterology, 50: 586 (1966).

27. Schneider, W. C.: Phosphorus compounds in animal tissues. I. Extraction and estimation of deoxypentose nucleic acid and of pentose nucleic acid. J. Biol. Chem., 161: 293 (1945).

28. Short, E. M., Elsas, L. J., and Rosenberg, L. E.: Effect of parathyroid hormone on renal tubular reabsorption of amino acids. Metabolism, 23: 715 (1974).

29. Sladen, G. E. and Dawson, A. M.: Interrelationships between the absorption of glucose, sodium and water by the normal human jejunum. Clin. Sci., 36: 119 (1969).

30. Spencer, R. P.: Intestinal Absorption of Aminoacids. Am. J. Clin. Nutr., 22: 292 (1969).

31. Suhadolnik, R. J.: Nucleoside Antibiotics p. 43. (Wiley Interscience, New York 1970).

32. Wapnir, R. A. and Lifshitz, F.: Absorption of amino acids in malnourished rats. J. Nutr., 104: 843 (1974).

33. Wilkinson, G. N.: Statistical Estimations in Enzyme Kinetics. Biochem. J., 80: 324 (1961).

34. Wiseman, G.: Absorption of amino acids in "Handbook of Physiology" Code C. F., edit, Section 6, Vol. 3, p. 1277, (Amer Physiol Soc., Washington, D.C., 1968).

35. Yarmolinsky, R. D. and Haba de La, G. L.: Inhibition by puromycin of aminoacid incorporation into protein. Proc. Nat. Acad. Sci., 45: 1721 (1959).

36. Yssing, M., Jensen, H., and Jarnum, S.: Albumin metabolism and gastrointestinal protein loss in children with nephrotic syndrome. Acta Paediatr. Scand., 58: 109 (1969).

37. Charles River, Wilmington, Mass.

38. Purina Lab Chow, Ralston-Purina Co., St. Louis, Mo.

39. Sigma Chemical Corp., St. Louis, Mo.

40. Harvard Instruments, Mills, Mo.

41. New England Nuclear, Coston, Mass.

42. J. T. Barker Co., Phillipsburgh, N.J.

43. Instrumentation Laboratory, Boston, Mass.

44. BUN-TEL, Pfizer, Inc. New York, New York.

45. We gratefully acknowledge the assistance of Kristina Mrozinska, Lori Strand and Rosemary Kenney in the preparation of this manuscript.

46. This investigation was supported in part by a grant from The Shubert Foundation and USPHS - Grant 1 SO 8 RR 09128-01A1.

47. Requests for reprints should be addressed to: Dr. Melinda McVicar, Department of Pediatrics, North Shore University Hospital, 300 Community Dr., Manhasset, N.Y. 11030.

48. Received for publication February 11, 1981.

49. Accepted for publication December 14, 1982.

\title{
Enhancement of Sodium Excretion by Substance $P$ during Saline Loading in the Canine Puppy
}

\author{
ROBERT D. FILDES, ${ }^{(40)}$ MICHAEL SOLHAUG, NICK TAVANI, JR., GILBERT EISNER, \\ PHILIP CALCAGNO, AND PEDRO A. JOSE
}

Department of Pediatrics, Georgetown University Medical Center, 3800 Reservoir Road, N.W., Washington, D.C. 20007, USA

\section{Summary}

Saline loading in puppies results in an attenuated natriuresis when compared to the normal response by adult animals to the same degree of volume expansion. To characterize an eventual role for kinins in the diuretic response by puppies to saline loading, two experimental protocols were constructed to evaluate the effect of substance $P$ infusion during baseline hydration and acute saline loading. Low dose $\left(10 \mathrm{ng} \cdot \mathrm{kg}^{-1} \cdot \mathrm{min}^{-1}\right)$ infusion of substance $P$ during basal conditions did not affect urine flow, sodium excretion or glomerular filtration rate (GFR). The addition of saline loading to the ongoing low dose infusion of substance $P$ produced an increase in urine flow from 3.73 to $12 \mu \mathrm{l} \cdot \mathrm{min}^{-1} \cdot \mathrm{g}^{-1}$ kidney weight and resulted in a marked increase in urinary sodium excretion from 110 to $851 \mu \mathrm{Eq} \cdot \mathrm{min}^{-1} \cdot \mathrm{g}^{-1}$ kidney weight. These increases in urine flow and urinary sodium excretion during low dose sub- stance $P$ infusion were significantly greater than those observed during saline loading alone. No significant effect on GFR was observed during either saline loading alone or low dose substance $P$ during saline loading. In Protocol II, the infusion of low dose substance $P$ during an ongoing saline load enhanced diuresis and natriuresis to a greater extent than those receiving only a saline load without affecting GFR. The high dose infusion of substance P $\left(100 \mathrm{ng} \cdot \mathrm{kg}^{-1} \cdot \mathrm{min}^{-1}\right)$ during baseline hydration resulted in a natriuresis and diuresis that persisted during the addition of saline despite a significant fall in GFR. Saline loading alone resulted in increased urinary kallikrein activity and the infusion of substance P $\left(10 \mathrm{ng} \cdot \mathrm{kg}^{-1} \cdot \mathrm{min}^{-1}\right)$ increased urinary kallikrein activity even further. A significant positive correlation between urinary sodium excretion and urine kallikrein activity was found $(r=0.91, P<$ 0.01). 


\section{Abbreviations}

GFR, glomerular filtration rate

$T$, tosyl-arginine

$\mathrm{U}_{\mathrm{Na}} \mathrm{V}$, absolute urinary sodium excretion

The neonate in many species has a characteristic inability to excrete a saline load as rapidly and efficiently as its adult counterpart $(2,3,4,14,18)$. Among the factors considered to be important contributors to this phenomenon are a lower basal GFR, the pattern of intrarenal distribution of blood flow with a predominance of the juxtamedullary nephrons, and particularly, a greater distal avidity for sodium reabsorption $(5,18,19,31)$. The latter has been demonstrated in both human neonates and puppies and it has been suggested that there is a heterogenous development of the nephron with a relative structural and functional predominance of the distal tubule in early life, which would respond to the high aldosterone levels characteristic of the neonate $(5,15,31$, $32,34,37$ ).

There are several hormones locally formed and released that have been thought to modify sodium excretion by the kidney. In particular, the role of the renal kallikrein system in the regulation of sodium and water excretion by the kidney has evoked great interest $(8,20,23,25)$. Kallidin and/or bradykinin may facilitate sodium excretion during periods of natriuresis $(23,35)$. Urinary kallikrein levels are low in infants, and it is therefore plausible that decreased activity of the kallikrein/kinin system in the newborn may contribute to the neonate's lesser ability to excrete a salt load (36). The purpose of our study was to evaluate the effect of substance $P$, an undecapeptide known to increase the release or activation of renal kallikrein $(21,22,26)$ on the ability of puppies under $3 \mathrm{wk}$ of age to excrete an imposed saline load.

\section{MATERIALS AND METHODS}

Thirty-five mongrel puppies of either sex, aged 1-23 days, were successfully studied. The puppies remained with the mother until $1 \mathrm{~h}$ before the experiment. Body weight of the puppies ranged $0.3-$ $1.3 \mathrm{~kg}$. The puppies were anesthetized with pentobarbital (12-22 $\mathrm{mg} / \mathrm{kg}$ body weight) and placed on a thermoregulated table for control of body temperature at $37.0-37.5^{\circ} \mathrm{C}$. Surgical preparation was begun with the insertion of an endotracheal tube for assisted ventilation. Polyethylene catheters of appropriate size were placed in the left external jugular vein for infusion of $\left[{ }^{3} \mathrm{H}\right]$ labeled inulin in $D_{5} E_{48}$ electrolyte solution, the right external jugular vein for the infusion of substance $P$ or its vehicle, the right femoral vein for the infusion of the saline load, and the right femoral artery for monitoring of blood pressure and blood sampling. Both ureters were catheterized via suprapubic incision for collection of urine.
All animals were infused with a standard electrolyte solution $\left(D_{5} E_{48}\right.$-Travenol) at $0.06 \mathrm{ml} \cdot \mathrm{min}^{-1} \cdot \mathrm{kg}^{-1}$ body weight. A priming injection of $\left[{ }^{3} \mathrm{H}\right]$ labeled inulin, $3-5 \mu \mathrm{Ci} / \mathrm{kg}$ body weight, was followed by a constant infusion of $\left[{ }^{3} \mathrm{H}\right]$ labeled inulin at a rate of $0.06 \mu \mathrm{Ci} \cdot \mathrm{min}^{-1} \cdot \mathrm{kg}^{-1}$ body weight. Surgical losses were replaced before equilibration and arterial blood gases were monitored throughout the experiment, with adjustments made in the assisted ventilation to maintain the arterial $\mathrm{pH}$ at $7.4, \mathrm{Po}_{2}$ at $60-90 \mathrm{mmHg}$ and $\mathrm{PCO}_{2}$ at 35 with bicarbonate at $16-22 \mathrm{mEq} / \mathrm{liter}$. Blood samples were obtained as midpoint specimen during timed urine collections and were used for measurement of hematocrit, serum protein, and plasma sodium as well as inulin concentration. After a 1-h equilibration period, three timed urine collections of approximately $5 \mathrm{~min}$ each were obtained before any fluid or drug manipulations (baseline Period I) for inulin clearances and fractional excretion of sodium. Subsequently, the manipulations of the animals depended upon the experimental protocol followed.

Protocol I (Baseline-test infusion-saline load). The purpose of this protocol was to measure the renal response to an infusion of substance $P$ or placebo (vehicle- $D_{5} E_{48}$ ) before (Period II) and subsequently during saline loading (Period III). In three separate groups of puppies, after the baseline clearance period, the animal received either $\mathrm{D}_{5} \mathrm{E}_{48}$ alone (control group, $n=7$ ), $\mathrm{D}_{5} \mathrm{E}_{48}$ with substance $P$ at $10 \mathrm{ng} \cdot \mathrm{kg}^{-1} \cdot \mathrm{min}^{-1}$ (experimental group $\mathrm{A}, \boldsymbol{n}=7$ ) or $D_{6} E_{48}$ with substance $P$ at $100 \mathrm{ng} \cdot \mathrm{kg}^{-1} \cdot \mathrm{min}^{-1}$ (Experimental group $\mathrm{B}, \boldsymbol{n}=7$ ). The overall rate of delivery of baseline fluids was maintained at $0.06 \mathrm{ml} \cdot \mathrm{kg}^{-1} \cdot \mathrm{min}^{-1}$ throughout the remainder of the experiment. The test solutions were coded so that the experimenter was unaware of their identities. Urinary losses were not replaced. After a 30-min equilibration period, a set of three 5-min urine clearances was obtained (Period II). This was followed by saline loading at $2 \mathrm{ml} \cdot \mathrm{kg}^{-1} \cdot \mathrm{min}^{-1}$ for $15 \mathrm{~min}$ and then at $0.5 \mathrm{ml}$. $\mathrm{kg}^{-1} \cdot \mathrm{min}^{-1}$ until the end of the experiment. Thirty minutes after the initiation of saline loading, the final set of clearances was begun (Period III).

Protocol II (Baseline-saline loading-test infusion). In additional studies using low dose substance $P\left(10 \mathrm{ng} \cdot \mathrm{kg}^{-1} \cdot \mathrm{min}^{-1}\right)$ the sequence of test infusion followed by saline loading was reversed. In seven matched littermate paired puppies after the clearance period during basal conditions (Period I) each animal was given isotonic saline infused at a rate of $2 \mathrm{ml} \cdot \mathrm{kg}^{-1} \cdot \mathrm{min}^{-1}$ for $15 \mathrm{~min}$, then at a rate of $0.5 \mathrm{ml} \cdot \mathrm{kg}^{-1} \cdot \mathrm{min}^{-1}$ until the end of the experiment. Thirty minutes after the start of the saline load, three 5-min urine collections were again obtained for inulin clearance and fractional excretion of sodium (Period II). After these collections one animal of each pair received $D_{6} E_{48}$ alone and the others received $D_{5} E_{48}$ with substance $P\left(10 \mathrm{ng} \cdot \mathrm{kg}^{-1} \cdot \mathrm{min}^{-1}\right)$ concomitant with the saline infusion. Thirty minutes after the start of the test infusion the final set of clearances was begun (Period III). Urinary kallikrein activity

Table 1. Data from animals in protocol I using low dose substance $P\left(10 \mathrm{ng} \cdot \mathrm{kg}^{-1} \cdot \mathrm{min}^{-1}\right)$. In these experiments siblings were randomized into one group to serve as control $(n=7)$ aged $13.25 \pm 4.89$ days, weight $=846.72 \pm 432.16 \mathrm{~g}$, and a second group, Experimental $A$ ( $n$ $=7)$ composed of paired siblings aged $15.26 \pm 5.67$; weight $=864.14 \pm 465.75 \mathrm{~g}$, which were studied within 1 day of the paired control

\begin{tabular}{|c|c|c|c|c|c|c|}
\hline & \multicolumn{2}{|c|}{$\begin{array}{c}\text { I } \\
\text { Basal }\end{array}$} & \multicolumn{2}{|c|}{$\frac{\text { II }}{\text { Basal + Test Infusion }}$} & \multicolumn{2}{|c|}{$\begin{array}{c}\text { III } \\
\text { Saline Load + Test Infusion }\end{array}$} \\
\hline & Control & Experimental A & Control & Experimental A & Control & Experimental A \\
\hline MAP (mmHg) & \pm 8.48 & \pm 10.36 & \pm 6.54 & \pm 7.33 & \pm 5.87 & \pm 7.36 \\
\hline \multirow[t]{2}{*}{$V\left(\mu l \cdot \min ^{-1} \cdot g^{-1} K W\right)$} & 4.60 & 3.93 & 4.91 & 3.73 & 4.58 & $12.00^{1}$ \\
\hline & \pm 1.22 & \pm 0.77 & \pm 1.42 & \pm 0.97 & \pm 1.06 & \pm 1.67 \\
\hline \multirow[t]{2}{*}{$\mathrm{U}_{\mathrm{Na}} \mathrm{V}\left(\mathrm{mEq} \cdot \mathrm{min}^{-1} \cdot \mathrm{g}^{-1} \mathrm{KW}\right)$} & 208 & 113 & 177 & 110 & 282 & $851^{1}$ \\
\hline & \pm 61 & \pm 29 & \pm 57 & \pm 22 & \pm 82 & \pm 170 \\
\hline \multirow[t]{2}{*}{$\% \mathrm{~F}_{e x} \mathrm{Na}$} & 1.51 & 0.69 & 1.29 & 0.78 & 2.48 & $4.38^{2}$ \\
\hline & \pm 0.29 & \pm 0.17 & \pm 0.20 & \pm 0.21 & \pm 0.70 & \pm 1.09 \\
\hline
\end{tabular}

\footnotetext{
${ }^{1}$ III vs II, $P<0.01$.
}

${ }^{2}$ III vs II, $P<0.05$.

Abbreviations: MAP, mean arterial pressure; $V$, volume; GFR, glomerular filtration rate; $U_{N_{a}} V$, absolute urinary sodium excretion; $F_{\text {ex }} N a$, fractional sodium excretion. 
was measured in seven of the puppies studied during basal conditions. Urinary kallikrein was also measured in three of these puppies during saline loading alone and in four during saline loading with substance $P$.

Analytical methods. Plasma and urine samples $(2 \mu \mathrm{l})$ were placed in Liquiscint solution (National Diagnostics) for scintillation counting (Beckman LS 7500) of tritium. Glomerular filtration rate was equated with the inulin clearance and is expressed in $\mu \mathrm{l}$. $\mathrm{min}^{-1} \cdot \mathrm{g}^{-1}$ wet kidney weight. The sodium concentration of plasma and urine samples was determined using a flame photometer (NILAB-model 4-7016) on $50 \mu \mathrm{l}$ samples against a lithium standard. Arterial blood gases were measured with the System 1303$\mathrm{pH} /$ blood gas analyzer (Instrumentation Laboratories). Hematocrit was measured on all blood samples using heparinized microcapillary tubes $(50 \mu \mathrm{l})$ centrifuged at $10,000 \mathrm{rpm}$ for $5 \mathrm{~min}$. Total plasma protein was measured using a standard refractometer (American Optical Co.). Kallikrein in urine was estimated by its esterase activity on $\mathrm{T}$ in $\mathrm{micromoles} \mathrm{T} \cdot \mathrm{min}^{-1} \cdot \mathrm{g}^{-1}$ kidney weight (25).

Table 2. Data from animals in Protocol I using high dose substance $P\left(100 \mathrm{ng} \cdot \mathrm{kg}^{-1} \cdot \mathrm{min}^{-1}\right)$. In these experiments a group of $(n=7)$, Experimental $B$, aged $13.85 \pm 6.36$ days, weight $=823.28$ $\pm 436.28 \mathrm{~g}$ were studied

\begin{tabular}{|c|c|c|c|}
\hline & $\begin{array}{c}\text { I } \\
\text { Basal, } \\
\text { Experi- } \\
\text { mental B }\end{array}$ & $\begin{array}{c}\text { Il } \\
\text { Basal, } \\
\text { Test } \\
\text { Infusion, } \\
\text { Experi- } \\
\text { mental B }\end{array}$ & $\begin{array}{c}\text { III } \\
\text { Saline } \\
\text { Load + } \\
\text { Test } \\
\text { Infusion, } \\
\text { Experi- } \\
\text { mental B }\end{array}$ \\
\hline \multirow[t]{2}{*}{ Map (mmHg) } & 50.24 & 43.21 & 47.62 \\
\hline & \pm 10.37 & \pm 9.26 & \pm 8.55 \\
\hline$V\left(\mu l \cdot \min ^{-1} \cdot g^{-1} K W\right)$ & $\begin{array}{r}6.10 \\
\pm 1.50\end{array}$ & $\begin{array}{r}7.31 \\
\pm 1.39\end{array}$ & $\begin{array}{r}5.10 \\
\pm 0.80\end{array}$ \\
\hline \multirow[t]{2}{*}{ GFR $\left(\mu 1 \cdot \min ^{-1} \cdot g^{-1} \mathrm{KW}\right)$} & 204 & 197 & $95^{1}$ \\
\hline & \pm 19 & \pm 29 & \pm 26 \\
\hline \multirow{2}{*}{$\mathrm{U}_{\mathrm{N}} \mathrm{V}\left(\mu \mathrm{Eq} \cdot \mathrm{min}^{-1} \cdot \mathrm{g}^{-1} \mathrm{KW}\right)$} & 98 & 155 & $327^{1,4}$ \\
\hline & \pm 18 & \pm 28 & \pm 76 \\
\hline$\phi_{0} \mathrm{~F}_{\text {ex }} \mathrm{Na}$ & $\begin{array}{r}0.84 \\
\pm 0.49\end{array}$ & $\begin{array}{r}1.33^{3} \\
\pm 0.55\end{array}$ & $\begin{aligned} & 4.25^{2,4} \\
&+1.39\end{aligned}$ \\
\hline
\end{tabular}

${ }^{1}$ III vs II, $P<0.05$.

${ }^{2}$ III vs II, $P<0.06$.

${ }^{3}$ II vs I, $P<0.05$.

${ }^{4}$ III vs I, $P<0.01$.

Abbreviations, see Table 1
Statistical analysis. All data are expressed as mean \pm S.E.M. Statistical analysis of data was performed using the two-tailed $t$ test for paired and group data with the level of significance at $\leq$ 0.05 .

\section{RESULTS}

Results from animals in Protocol I are summarized in Tables 1 and 2. Table 1 summarizes the effect of low dose substance $P$ in seven matched sibling puppies. Urine flow, absolute and fractional sodium excretions were similar in both groups during the basal period and were not affected by infusion of $D_{5} E_{48}$ solution or low dose substance $P$. Infusion of low dose substance $P$, saline loading alone, or saline loading with substance $P$ did not significantly affect GFR.

Saline loading alone did not effect a significant increase in urine flow in the control animal; however, infusion of substance $P$ during saline loading produced an increase in urine flow from 3.73 to $12 \mu \mathrm{l} \cdot \mathrm{min}^{-\mathrm{P}} \cdot \mathrm{g}^{-1}$ kidney weight. Saline loading alone produced a slight but insignificant increase in both absolute and fractional sodium excretion. The continuation of saline loading and substance $P$ infusion resulted in a marked increase in urinary sodium excretion from 110 to $851 \mu \mathrm{Eq} \cdot \mathrm{min}^{-1} \cdot \mathrm{g}^{-1} \mathrm{kidney}$ weight. The magnitude of change in fractional sodium excretion of those puppies receiving saline loading alone was only $1 \%$ compared to a change of $3.68 \%$ in those receiving substance $P$ with saline loading $(P<0.05$, Table 1$)$.

Table 2 summarizes the effects of high dose substance $P 100 \mathrm{ng}$. $\mathrm{kg}^{-1} \cdot \mathrm{min}^{-1}$ in seven unpaired puppies. At this dose of substance $P$ a significant increase in fractional sodium excretion was seen compared to basal hydration alone $(P<0.05)$. A significant fall in mean GFR, $47 \%$, without any change in mean arterial pressure, occurred when saline loading was added to high dose substance $P$ infusion. Despite this drop in GFR, saline loading added to the substance $\mathbf{P}$ infusion produced a further increase in absolute and fractional urinary sodium excretion.

Table 3 summarizes the results from seven matched sibling puppies studied in Protocol II. Saline loading alone resulted in a significant increase in urinary flow rate when compared to the baseline state in both groups. Continued saline loading alone did not further increase urinary flow rates, whereas the infusion of substance $P$ during saline loading did result in a further increase, although not to a significant level. GFR was not altered significantly by saline loading alone or by substance $P$. Urinary sodium excretion significantly increased during saline loading when compared to the basal state in both groups. Continued saline infusion alone did not further increase absolute urinary sodium excretion, whereas the addition of substance $P$ to ongoing saline infusion resulted in a dramatic increase in $\mathrm{U}_{\mathrm{Na}} \mathrm{V}(P<0.01)$. The effect of

Table 3. Data from animals in Protocol II using low dose substance $P\left(10 \mathrm{ng} \cdot \mathrm{kg}^{-1} \cdot \mathrm{min}^{-1}\right)$. In these experiments, siblings were randomized into one group to serve as control $(n=7)$, aged 12.97 days, weight $750.34 \pm 364.49 \mathrm{~g}$, and a second group, Experimental $C$ $(n=7)$ composed of paired siblings aged 12.64 days, weight $=769.935 \pm 379.62 \mathrm{~g}$, which were studied within 1 day of the paired control

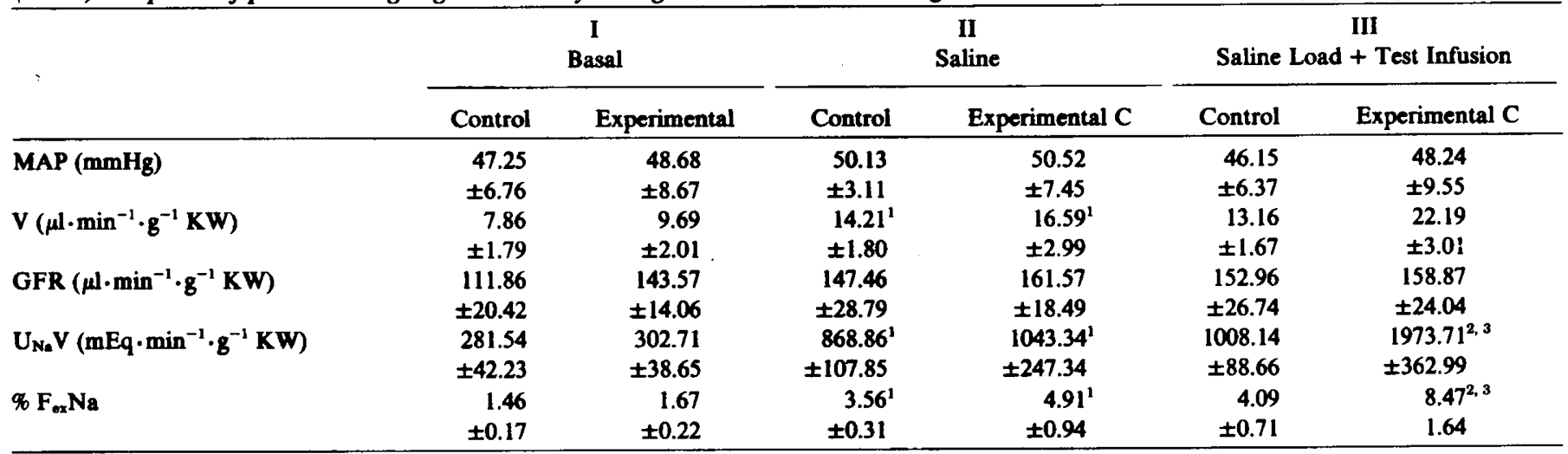

${ }^{1} P<0.05$, I vs II (paired $t$ test).

${ }^{2} P<0.05$, II vs III (paired $t$ test).

${ }^{3} P<0.05$, control vs Experimental (grouped data).

Abbreviations, see Table 1. 


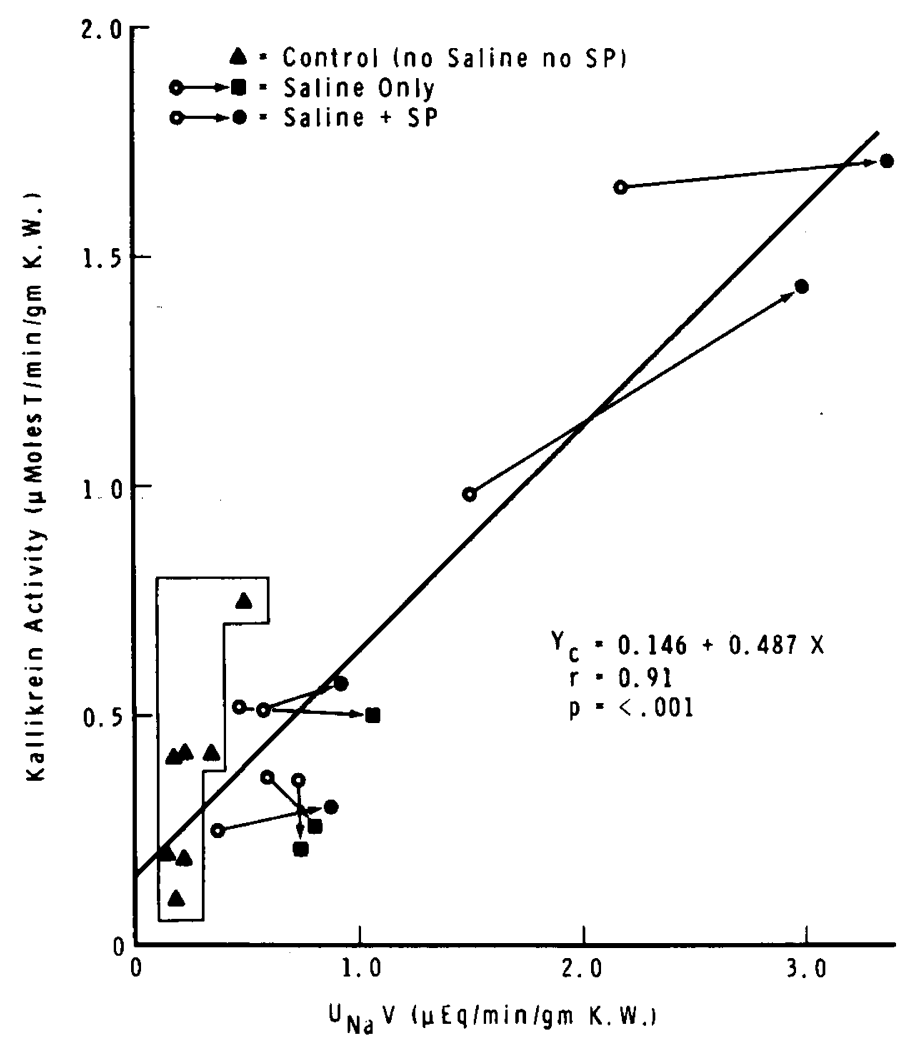

Fig. 1. Relationship between urinary kallikrein activity ( $\mu$ mole $T$. $\min ^{-1} \cdot g^{-1}$ kidney weight) and the absolute urinary excretion of sodium $\mathrm{U}_{\mathrm{Na}} \mathrm{V}\left(\mu \mathrm{Eq} \cdot \min ^{-1} \cdot \mathrm{g}^{-1}\right.$ kidney weight). Solid triangles represent seven puppies studied before the administration of saline or substance P. Open circles represent these puppies during saline loading. Four puppies then received substance $P$ infusion $\left(10 \mathrm{ng} \cdot \mathrm{kg}^{-1} \cdot \mathrm{min}^{-1}\right.$ ) during continued saline loading, solid circles, whereas three puppies continued to receive saline alone, solid squares.

saline loading on fractional excretion of sodium followed the same pattern.

Saline loading alone resulted in increased urinary kallikrein activity in six of the seven puppies examined $(0.37 \pm 0.08$ during control versus $0.66 \pm 0.18 \mu \mathrm{mol} \mathrm{T} \cdot \mathrm{min}^{-1} \cdot \mathrm{g}^{-1} \mathrm{kidney}$ weight during saline loading; $P<0.05$, Wilcoxon test). The infusion of substance $P$ during saline loading increased urinary kallikrein activity even further in all four animals in which it was measured $(0.85 \pm 0.34$ during saline loading alone versus $1.00 \pm 0.35 \mu \mathrm{mole} T \cdot \mathrm{min}^{-1}$. $\mathrm{g}^{-1}$ kidney weight during saline loading with substance $P$ infusion); however, because of the small sample size, significance was not achieved. Nevertheless, a significant positive correlation between urinary sodium excretion and urine kallikrein activity was found ( $r=0.91, P<0.001$, Fig. 1 ).

\section{DISCUSSION}

Substance $P$, when infused into the renal artery of adult dogs, produces a marked increase in renal blood flow, diuresis, natriuresis, and kaliuresis $(21,22,26)$. In the present studies, intravenous administration to puppies at a rate of $10 \mathrm{ng} \cdot \mathrm{kg}^{-1}$. $\mathrm{min}^{-1}$ had no effect but substance $P$ did produce an increase in fractional and absolute sodium excretion when infused at $100 \mathrm{ng}$. $\mathrm{kg}^{-1} \cdot \mathrm{min}^{-1}$. No comparison can be made between the sensitivity of the adult and neonate kidney to substance $P$ because our studies employed intravenous infusion and the adult studies used intrarterial infusion.

It is of interest that in our studies even the lower dose of substance $P$ was capable of markedly facilitating the natriuretic response to acute saline loading. The activation or release of kallikrein by substance $P$ in salivary glands as well as in the kidney, and the positive correlation obtained between the effects of substance $P$ on the kidney and increases in urinary kallikrein excretion, suggest that the renal effect of substance $P$ could be the result of intrarenal kinin formation. Anti-bradykinin serum (crossreactive with kallidin) decreased sodium excretion after saline infusion in rats by $50 \%$ (24), suggesting that kinins contribute to the natriuresis of volume expansion.

Many, but not all, animal and human studies have reported that kallikrein excretion varies directly with dietary salt and is increased during saline loading in dogs $(1,9,10,11,12,20)$. Levels of urinary kallikrein are low in infants (36). It appears possible, then, that decreased activity of the kallikrein/kinin system in the newborn may contribute to the neonate's lesser ability to excrete a salt load.

Urinary kallikrein activity reflects the active synthesis and secretion of kallikrein by the kidney $(20,27)$. Urinary kallikrein activity, in our study, increased after saline loading and increased further after the infusion of substance P. A significant positive correlation between urinary sodium excretion was obtained, consistent with the findings of Mills et al. $(21,26)$. Although we did not, in this study, remove non-kallikrein urinary TAME esterase(s), the increase in urinary esterase activity in the absence of an increased GFR, makes it likely that we were measuring an increase in renal kallikrein activity.

It has recently been postulated that substance $P$-inergic nerves may be involved in kallikrein release (17). This observation raises the question of whether substance $P$ might be released by renal nerves. The fact that the kidney is such a rich source of the enzyme that catabolizes substance $P$ makes it difficult to ascertain whether this substance is in fact produced in the kidney. Kessler et al. (17) studied the regulation of substance $P$, a putative neurotransmitter in the superior sympathetic ganglion of the neonatal rat. They found that trans-synaptic impulses decrease substance $P$, probably via the mediation of post-synaptic sodium influx. If this observation applies to nerve endings as well, then one would anticipate that increased adrenergic activity in a nervous pathway would diminish substance $P$ levels throughout the tract. Because we have found increased adrenergic activity in the young $(13,16)$, the neonatal period may be characterized by a decreased amount of substance $\mathbf{P}$ and consequently, lower kallikrein activity. Therefore, in the newborn, decreased kallikrein/kinin activity could be intimately linked to a maturational process involving the neural control of diverse renal functions.

Scicli et al. (33) reported that ninety-percent of renal kallikrein output was localized in the cortex. Studies using stop-flow experiments indicated distal secretion of kallikrein. Immunofluorescent experiments have shown that antibodies to rat kallikrein localize in rat epithelial cells of the segment of the distal tubules between the macula densa and the collecting ducts (29). Recently Omata et al. (28) reported that $90 \%$ of total nephron kallikrein was localized in the granular portions of distal and cortical collecting tubules. These observations are consistent with the findings that bradykinin exerts its natriuretic effect in distal tubular segments $(8,30,35)$.

If the diuretic effect of substance $P$ is mediated via the kallikrein/kinin system one would expect an effect on the distal tubule, especially because it has been shown in the dog that bradykinin has no effect on proximal tubular sodium reabsorption (35). Arendhorst found that in hydropenic rats substance $P$ produces a reduction in absolute and fractional reabsorption of salt and water by the proximal tubule, unrelated to changes in plasma flow, single nephron filtration or intrarenal hydrostatic pressures (7). In that study, the diuresis obtained could not be solely explained by the effect of substance $P$ on the proximal tubule and the authors postulated a distal effect as well to account for their observations. It is possible that in rats substance $P$ has a direct effect on sodium and water transport in the proximal tubule, independent of any effects produced in the distal tubule. Such an effect, if present in our studies, may not have been evident because of the increased distal tubular avidity for sodium characteristic of the newborn (5, $18,31,32$ ). Only a larger dose of substance $P$ induced natriuresis in the hydropenic state $(21,22)$. The imposition of saline loading with its known effect on tubular reabsorption helped unmask the 
contributions of low dose substance $P$. Its site of action along the tubule, however, remains to be clarified.

The cause of the fall in GFR seen during high dose substance $P$ infusion combined with salt loading is not clear. It is worthy of mention that the GFR values for baseline controls in this group were higher than those generally obtained and that the fall occurred only when the animals received both infusions, not during substance $\mathbf{P}$ alone. Although there have been some reports of a decrease in GFR during saline loading (6) we did not find such a decrease in other protocols. Despite this decline in GFR, an increased natriuresis occurred during salt loading, although it did not achieve the magnitude seen in the remaining studies.

\section{REFERENCES AND NOTES}

1. Adetuyibi, A., and Mills, I. H.: Relation between urinary kallikrein and renal function, hypertension and excretion of sodium and water in man. Lancet, 2 : 203 (1972).

2. Aperia, A., Broberger, O., Thodenius, K., and Zetterstrom, R.: Renal response to an oral sodium load in newborn fullterm infants. Acta Paediatr. Scand., 61: 620 (1972).

3. Aperia, A., Broberger, O., Thodenius, X., and Zetterstrom, R.: Developmental study of the renal response to an oral salt load in preterm infants. Acta Paediatr. Scand., 63: 517 (1974).

4. Aperia, A., Broberger, O., and Herin, P.: Changes in renal hemodynamics and sodium excretion during saline infusion in lambs. Acta Physiol. Scand., 94: 442 (1975).

5. Aperia, A. and Elinder, G.: Distal tubular sodium reabsorption in the developing rat kidney. Am. J. Physiol., 240: 487 (1981)

6. Arant, Billy S., Jr.: Glomerulotubular balance following saline loading in the developing canine kidney. Am. J. Physiol., 235 (5): F417 (1978).

7. Arendhorst, W. J., Cook, M. A., Mills, I. H.: Effect of substance P on proximal tubular reabsorption in the rat. Am. J. Physiol., 230 (6): 1662 (1976).

8. Carretero, O. A. and Scicli, A. G.: Renal kallikrein: its localization and possible role in renal function. Fed. Proc., 35: 194 (1976).

9. Carretero, O. A. and Scicli, A. G.: The renal kallikrein-kinin system in human and experimental hypertension. Klin. Wochenschr., 56 (Suppl. I): 113 (1978).

10. Croxatto, H. R., Albertini, R., Arriagada, R., Roblero, J., Rojas, M., and Rosas, R.: Renal urinary kallikrein in normotensive and hypertensive rats during enhanced excretion of water and electrolytes. Clin. Sci. Mol. Med., 51: 259S (1976).

11. Croxatto, H. R., Huidobro, F., Rojas, M., Roblero, J., and Albertini, R.: The effect of water, sodium overloading and diuretics upon urinary kallikrein. Adv. Exp. Med. Biol., 70: 361 (1975)

12. DeBono, E. and Mills, I. H.: Simultaneous increases in kallikrein in renal lymph and urine during saline infusion. J. Physiol. (Lond.), 241: 127P (1978)

13. Felder, R. A., Pelayo, J. C., Calcagno, P. L., Eisner, G. M., and Jose, P. A.: Alpha adrenoceptors in the developing kidney. Pediatr. Res., 17: 177 (1983).

14. Goldsmith, D. I., Drukker, A., Blaufox, M. D., Edelmann, C. M., and Spitzer, A. Hemodynamic and excretory response of the neonatal kidney to acute volume expansion. Am. J. Physiol., 237 (5): F392 (1979).

15. Horster, M. and Valtin, H.: Postnatal development of renal function. Micropuncture and clearance studies in the dog. J. Clin. Invest., 50: 779 (1971)

16. Jose, P. A., Slotkoff, L. M., Lilienfield, L. S., Calcagno, P. L., and Eisner, G. M.: Sensitivity of neonatal renal vasculature to epinephrine. Am. J. Physiol., 226(4): 796 (1974)

17. Kessler, J. A Adler, J. E., Bohn, M. C., and Black, I. B.: Substance P in principal sympathetic nerves: regulation by impulse activity. Science, 214: 335 (1981).

18. Kleinman, L. I.: Renal sodium absorption during saline loading and distal blockade in newborn dogs. Am. J. Physiol., 228: 1403 (1975).

19. Kleinman, L. I. and Reuter, J. H.: Renal response of the newborn dog to a saline load: the role of intrarenal blood flow distribution. J. Physiol. (Lond.), 239: 225 (1974).

20. Levinsky, Norman G.: The renal kallikrein-kinin system. Circ. Res., 44 (4): 441 (1979).

21. McFarlane, N. A. A., Mills, I. H., and Ward, P. E.: The diuretic and natriuretic effects of arterial infusions of substance $P$ and their relationship to kallikrein excretion. J. Physiol. (Lond.), 239: 28P (1974).

22. MacFarlane, N. A. A., Ward, P. E., and Mills, I. H.: Kallikrein-like actions of arterial infusions of microgram doses of substance P. J. Endocrinology, 63: 40 (1974).

23. Marin-Grez, $M$. Cottone, $P$, and Carretero, O. A.: Evidence for an involvement of kinins in regulation of sodium excretion. Am. J. Physiol., 223: 794 (1972).

24. Marin-Grez $M$ : The influence of antibodies against bradykinin on isotonic saline diuresis in the rat: evidence for kinin involvement in renal function. Pfluegers Arch., 350: 231 (1974).

25. Mills, I. H., MacFarlane, N. A. A., Ward, P. E., and Obika, L. F. O.: The rena kallikrein system and the regulation of salt and water excretion. Fed. Proc., 35: 181 (1976).

26. Mills, I. H., McFarlane, N. A. A., and Ward, P. E.: Increase in kallikrein excretion during the natriuresis produced by arterial infusion of substance $\mathbf{P}$. Nature, 257: 108 (1974).

27. Mills, I. H., Paterson, C., and Ward, P. E.: The role of the kidney in the inactivation of injected ${ }^{126}$ I-kallikrein. J. Physiol. (Lond.), 251: 281 (1975).

28. Omata, K., Carretero, O. A., Scicli, A. G., and Jackson, B.: Localization of kallikrein in isolated tubular segments of the rabbit nephron. Kidney Intern. (Abstract), 21: 263 (1982).

29. Ostavik, T. B., Nustad, K., Brandtzaeg, P., and Pierce, J. V.: Cellular origin of urinary kallikreins. J. Histochem. Cytochem., 24: 1037 (1976).

30. Schneider, E. G., Strandhoy, J. W., Willis, L. R., and Knox, F. G.: Relationships between proximal sodium reabsorption and excretion of calcium, magnesium and phosphate. Kidney Intern, 4: 369 (1973).

31. Schoeneman, M. J. and Spitzer, A.: The effect of intravascular volume expansion on proximal tubular reabsorption during development. Proc. Soc. Exp. Biol. Med., 165: 319 (1980)

32. Schoeneman, M. and Spitzer, A.: Sodium reabsorption during maturation. Kidney Intern, 10: 598 (1976)

33. Scicli, A. G., Carretero, A. A., Hamton, A., Cortes, P., and Oza, N. B.: Site of kinogenase secretion in the dog nephron. Am. J. Physiol., 220: 533 (1976).

34. Spitzer, A. and Brandis, M.: Function and morphologic maturation of superficia nephrons: relationship to total kidney function. J. Clin. Invest., 53: 279 (1974).

35. Stein, J. H., Congbalag, R. C., Karsh, D. L., Osgood, R. W., and Ferris, T. F. The effect of bradykinin on proximal tubular sodium reabsorption in the dog. Evidence for functional nephron heterogeneity. J. Clin. Invest., 51: 1709 (1972).

36. Tortorolo, G., Procelli, G., and Cuatalo, P.: Urinary kallikrein in premature, small at term and normal newborns and in children. In: Pisano, J. J., Austen, K. F.: Chemistry and Biology of Kallikrein: Kinin System in Health and Disease. p. 433. DHEW Publication (NIH) 776.

37. Zink, H. and Horster, M.: Maturation of dilutory capacity in loops of Henle of rat superficial nephrons. Am. J. Physiol., 233: F519 (1979).

38. A preliminary report of this work was presented at the Annual Meeting of the American Pediatric Society and Society for Pediatric Research, Atlanta, Georgia, May 4, 1979.

39. The authors thank Mrs. Carolyn Patterson for her secretarial assistance.

40. Requests for reprints should be addressed to: Robert D. Fildes, Georgetown Univ. Department of Pediatrics, 3800 Reservoir Road, N.W., Washington. D.C. 20007 (USA).

41. This work was supported in part by U. S. Public Health Service grants 79 HL 0386 and HL 07213.

42. Received for publication August 31, 1982

43. Accepted for publication March 9, 1983. 